ESJ Social Sciences

\title{
Sustainable Development and Economic Growth: A Reality or an Oxymoron?
}

\author{
El Chami Daniel \\ Timac Agro Italia S.p.A., S.P.13 \\ Località Ca' Nova I-26010, Ripalta Arpina (CR), Italy
}

Doi:10.19044/esj.2021.v17n41p1

Submitted: 24 November 2021

Accepted: 06 December 2021

Published: 31 December 2021
Copyright 2021 Author(s)

Under Creative Commons BY-NC-ND

4.0 OPEN ACCESS

Cite As:

El-Chami D. (2021). Sustainable Development and Economic Growth: A Reality or an Oxymoron?. European Scientific Journal, ESJ, 17 (41), 1.

https://doi.org/10.19044/esj.2021.v17n41p1

\section{Abstract}

The word "sustainable" is on everyone's lips and every publication; however, it is over-and misused as a trend for marketing and profit purposes, sometimes unethically for "greenwashing". This distortion creates an obstacle in creating a more sustainable world and leads authors to describe sustainable development and economic growth as oxymorons. This paper describes the relationship between sustainable development and economic growth and explains how sustainability reporting, particularly management, governance and social disclosures (GRI 100), could effectively stimulate economic growth. However, to reach a sustainable model, the paper recommends a mental and theoretical transformation in economic growth's perception to move from profit maximisation to optimisation. Finally, the manuscript calls to intensify research in this direction for a sustainable transformation of our society.

Keywords: Sustainable Development, Economic Growth, Profit Optimisation, Ethical Dimension, Environmental Pillar

\section{Introduction}

\section{Sustainable Development and Economic Growth}

Sustainability has been conceived as a development model to ensure generations' constant economic growth (Eisenmenger et al. 2020). The Bruntland Commission first defined It in 1987 as "development that meets the 
needs of the present generations without compromising the ability of future generations to meet their own needs" (UN General Assembly 1987). The definition has conceptualised the three-dimensional model with the pillars (Figure 1), where sustainability balances economic growth, social well-being and environmental protection.

Albeit somewhat vague, this concept has been widely adopted at high institutional levels to maintain economic advancement and progress while respecting high ethical standards, growing collective social responsibility, and protecting the environment's long-term value. Further, the Intergovernmental Panel on Climate Change (IPCC) has retained sustainable development fundamental for adapting our sectors to climate change uncertainty (IPCC 2001).

In another way, Adam Smith has founded his "free market" theory on moral behaviour and judgment for society's best interest (The theory of moral sentiments). However, capitalism lacked moral responsibility in practice, and decision-making exclusively sought profit maximisation at the expense of society's interests. Therefore, instead of profit maximisation, the sustainability model suggests an optimisation model to generate growth, internalising social well-being and environmental benefits to adding this missing ethical dimension, missing in the classical economic theory. Consequently, and according to the sustainability model, economic growth is intrinsically embedded in the sustainable development of organisations, but it also seeks to upsurge social and ecological ethics. This manuscript will describe the relationship between sustainable development and economic growth. The following section will represent the tools available for the sustainable model to create value and growth that reporting systems disclose as indicators for reporting. 


\section{Environmental Protection}

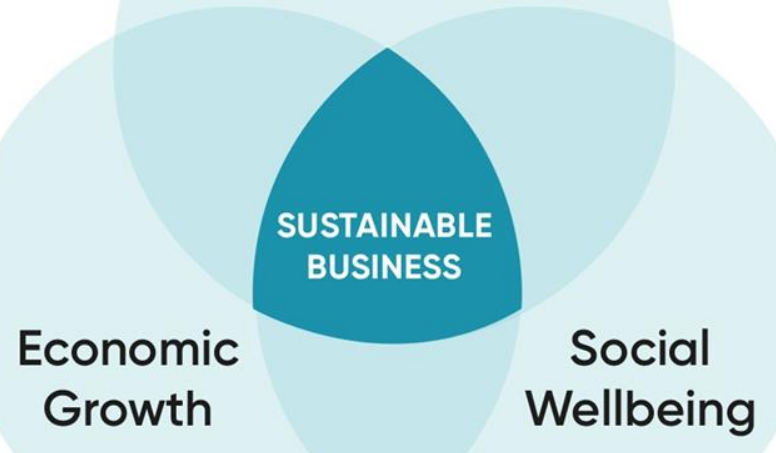

Figure 1: The sustainability model with the three-dimensional pillars.

\section{Tools for Sustainable Growth}

In practice, given the global interest in sustainability, the scientific community has proposed several sustainable decision-making, monitoring and evaluation tools. Indeed, several sustainability frameworks and standards recognised internationally, based on a set of three-dimensional indicators (economic, social and environmental), help quantify business progress achieved in terms of sustainability. These tools also contribute to the United Nations Sustainable Development Goals (UN-SDGs) by integrating common indicators. In particular, SDG 8, decent work and economic growth, promotes sustained, inclusive and sustainable economic growth, full and productive employment and decent work for all.

Sustainable decision-making and monitoring and evaluation tools are formally disclosed transparently in the non-financial reporting to inspire companies to develop a responsible business approach. The major nonfinancial reporting guidelines include:

- Global Reporting Initiative (GRI Sustainability Reporting Standards);

- The Organisation for Economic Co-operation and Development (OECD Guidelines for Multinational Enterprises);

- UN Global Compact (Communication on Progress);

- International Organisation for Standardisation: Guidance on social responsibility (ISO 26000);

- The IIRC International Framework (International Integrated Reporting Council). 
According to the United Nations, $89 \%$ of chief executives believe these tools are fundamental for companies' economic growth, and $90 \%$ feel personal responsibility (United Nations Global Compact; Accenture Strategy 2016). However, various studies have highlighted the existence of a social or environmental "legitimacy seeking" strategy behind this ethical responsibility (Christmann and Taylor 2006).

Despite the dominance of profit-seeking and legitimacy-seeking of corporate sustainability strategies (Schaltegger and Hörisch 2017), sustainability reporting includes valuable tools to build up companies' resilience to market uncertainties and the impacts of climate change. The dominant sets of disclosures include social and environmental disclosures and governance and management, which will be discussed in the following sections.

\subsection{Environmental Management}

The classical economic theory has recognised the trade-offs between economic growth and the environment and their correlation. Since the 1980s, many authors have raised the importance of environmental management for economic growth, especially for rural areas that intensively depend on natural resources for survival and development (Warford and Schramm 1987). Further, environmental assets contribute directly and indirectly in supporting economic activities (e.g. risk management, services provided, etc.). More recently, authors have addressed the importance of managing the environment and natural resources for growth and sustainable development (Costa 2021; Goosen 2012).

However, achieving sustainable economic growth requires the internalisation of negative externalities, which has been shown to reduce environmental and social impacts (Folkens et al. 2020; Eidelwein et al. 2018; García-Gusano et al. 2018). According to the literature, a complete decoupling of productive systems from environmental impacts by adopting innovative solutions to increase resources efficiency (Costa and Matias 2020; Everett et al. 2010).

\subsection{Human Resources Management}

A growing number of scientific evidence reveals an association between the human resources management approach adopted and any entity's high commitment and performance outcomes (Buller and McEvoy 2012; Guest 1997). The integration of sustainability in an entity's management model increases social responsibility and, consequently, employees' wellbeing and performances (Stofkova and Sukalova 2020), directly correlated to economic growth (Uysal 2017; Vlad et al. 2012). 
The characteristics of sustainable human resource management, according to Stankevičiūtė and Savanevičienè (2018), can be countless, all based on fairness, equality, health, safety, well-being and development. Sustainable human resource management has changed the approach towards employees from a mere input factor for production (to be exploited) to a resource with potential; employers should empower to motivate and express the maximum of their performances (Conger 2003). These characteristics require continuous and consistent attention to the following aspects:

- A selection procedure;

- A continuous follow up to assess weaknesses and opportunities;

- Design development programmes to increase skills and tools to overcome transform weaknesses in opportunities;

- Retribution and incentives;

- A balance between work and personal life;

- Procedures to prevent behaviour distortion and to encourage and protect those who expose such practices.

\subsection{Governance}

The notion of participation in decision-making or collective decisionmaking is as old as the democracy concept. However, it has always been associated with political thinking until the last few decades, when it emerged across many disciplines. This multi-disciplinary challenge arose with the growing expectations to influence citizens' decisions in sectors that could directly or indirectly interest or affect them (Chhotray and Stoker 2009). Therefore, the governance concept seeks to understand the way collective decision-making is built and its participatory implementation to ensure the governors' accountability to the governed (Schneider 1999).

In the private sector, Ong and Djajadikerta (2018) revealed a significant positive correlation between corporate governance, based on stakeholder theory, and sustainability, adopting a newly developed reporting index - Ong et al. (2016) Index - in a study investigating companies operating in the Australian resources industry. Similar scientific results revealed the importance of governance in different case studies to improve companies' sustainability (Costa 2021; Thistlethwaite and Menzies 2016; Krechovská and Procházková 2014). Furthermore, the effect of governance on economic growth has been abundantly assessed in both public and private sectors, and all studies confirmed a positive correlation [Gelb et al. 2019; Hadj et al. 2018; Liu et al. 2018; Emara et al. 2016).

Further, to bring long-term development, shared economic value to business and society, and innovative competitive advantage, successful governance strategies seek to implement effective stakeholder engagement to 
depict the material topics to determine the sustainability issues (Nair 2019; Camilleri 2015). Finally, sustainable governance confers balance, agility and adaptability to systems strengthening responses in crises such as COVID-19 (Janssen and van der Voort 2020).

\subsection{Risk Management}

The priority of the sustainability model is value creation rather than risk management. However, organisations retain that risk management helps monitor and manage risks and identify opportunities to impact value creation (Willumsen 2019).

Implementing risk management in a sustainability model is a newly emerging risk area, still unclearly approached (Schulte 2018). It requires a widening of the context analysis to align it with the three sustainability pillars, i.e. economic, social, and environmental (Anderson 2006), to design, deploy appropriate responses, measure and control progress of related risk-averse actions. Therefore, sustainability risk management helps identify and prevent emerging issues, increasing the business model's robustness and generating reputation, competitiveness and growth.

It is no surprise that the pandemic from the COVID-19 pandemic had a tremendous impact on the achievement of the goals in general and the economic growth in particular (SDG 8). Still, according to the United Nations (UN-SDG 2021), the economic recovery is underway (Figure 2), and risk management helps reduce trade-offs between different priorities and objectives (OECD 2020). 


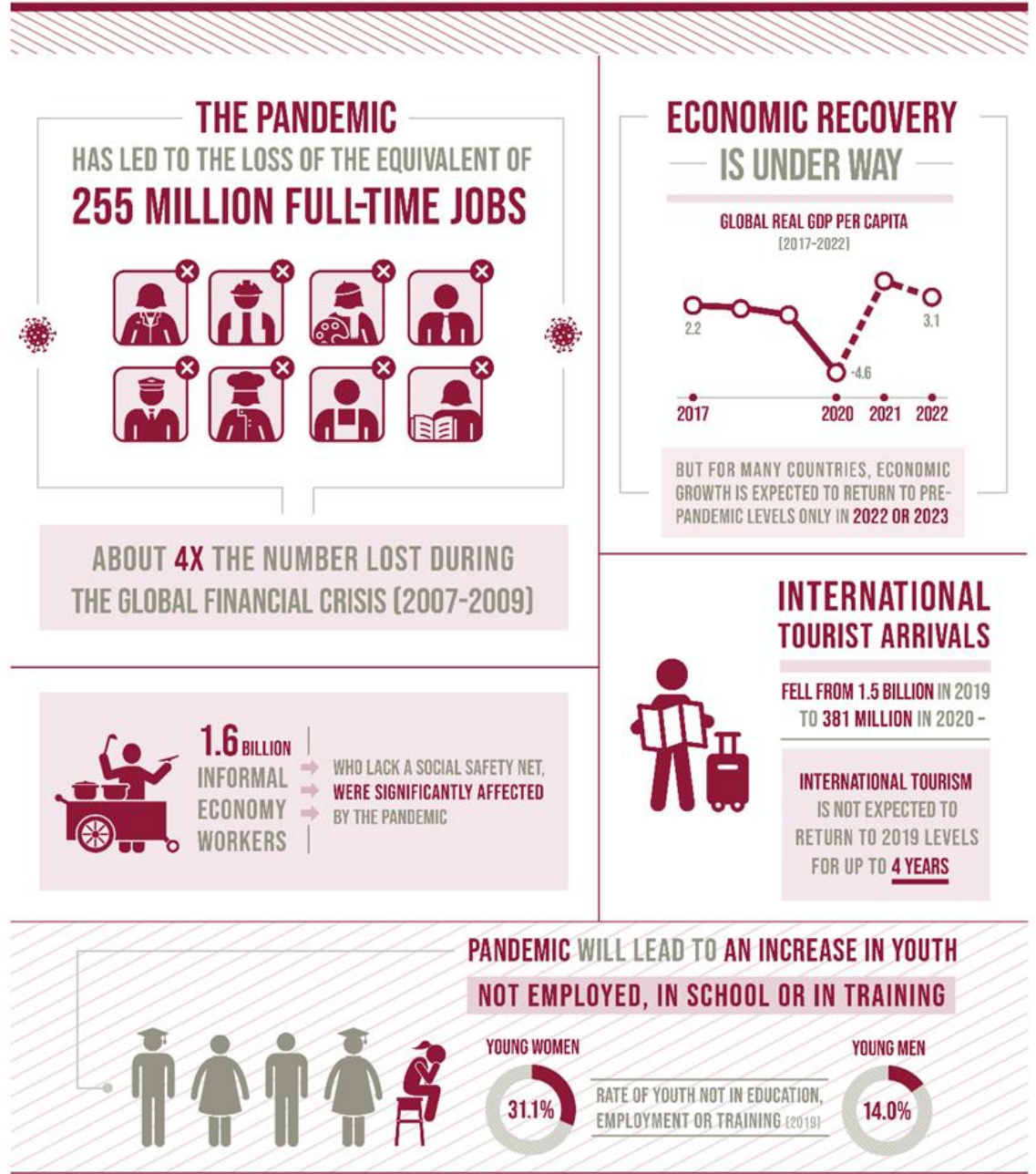

THE SUSTAINABLE DEVELOPMENT GOALS REPORT 2021: UNSTATS.UN.ORG/SDGS/REPORT/2021/

Figure 2: Overview of the impact of the pandemic from the COVID-19 on economic growth.

\section{Conclusion}

Nowadays, the word "sustainable" is on everyone's lips and on every publication, which, on one side, is good news. However, it is sad to know that it is over-and misused as a trend for marketing and profit purposes (Macellari 
et al. 2021), sometimes unethically for "greenwashing", when people have no o little idea what the word actually means, which constitutes a constraint towards creating a more sustainable world.

However, this manuscript showed a positive correlation found in the literature between sustainable development and economic growth; it also described the tools available in sustainability reporting for businesses and institutions to create growth in implementing the sustainable model (Figure 3). Therefore, sustainable development and economic growth is indeed a reality and is not at all an oxymoron. Yet, we need a theoretical and mental transformation to regard economic growth as profit optimisation rather than profit maximisation with ethical and social constraints, including social equity, well-being, security, natural capital development, and climate change mitigation. These are broad moral and social themes relevant for any business or institution in any location; other local topics could be applicable in specific conditions for sustainable development and should not be underestimated.

Finally, this manuscript highlighted the importance of sustainability thematics such as human resources management, environmental management, governance and risk management in generating economic. Some available literature supports this opinion, but scientific evidence still needs to be incremented with quantitative studies. Therefore, this opinion paper calls to intensify research in this direction for a sustainable transformation of our society. 


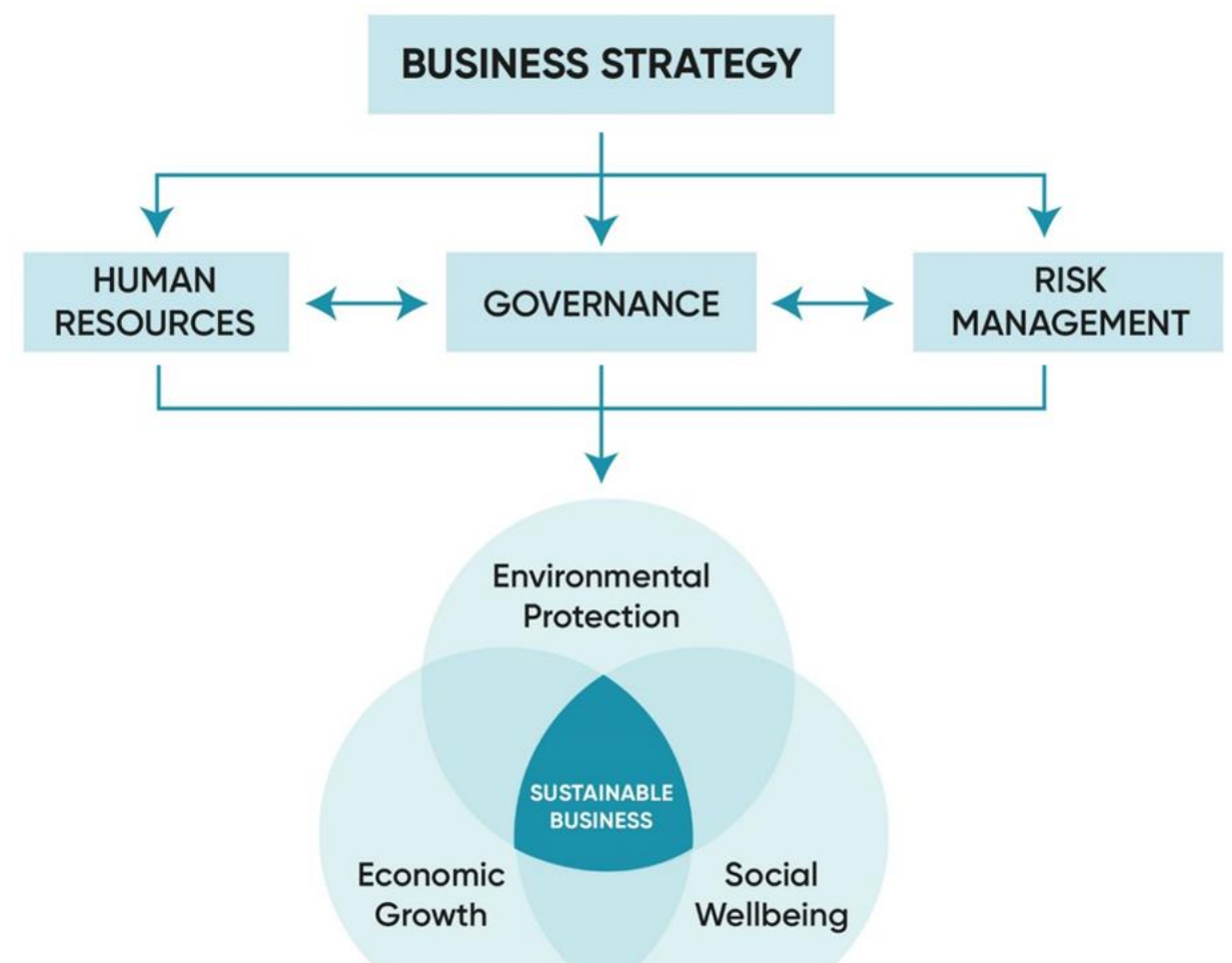

Figure 3: Schematic representation of tools available for sustainable businesses and institutions.

Funding: This research received no external funding.

Acknowledgements: The author would like to acknowledge the support of Ms Federica Belloni, who participated in the graphical conception of Figures 1 and 3.

Conflicts of Interest: The author declares no conflict of interest.

\section{References:}

1. Anderson, D.R. The critical importance of sustainability risk management. Risk Management 2006, 53 (4): 66-74.

2. Buller, P.F.; McEvoy, G.M. Strategy, human resource management and performance: Sharpening line of sight. Hum. Resour. Manag. Rev. 2012, 22 (1): 43-56. doi:10.1016/j.hrmr.2011.11.002

3. Camilleri, M.A. Valuing Stakeholder Engagement and Sustainability Reporting. Corporate Reputation Review 2015, 18 (3): 210-222. doi:10.1057/crr.2015.9 
4. Chhotray, V.; Stoker, G. Governance theory and practice: A CrossDisciplinary Approach. Palgrave Macmillan, Hampshire (UK) (2009): 296 p. doi: $10.1057 / 9780230583344$

5. Christmann, P.; Taylor, G. Firm self-regulation through international certifiable standards: determinants of symbolic versus substantive implementation. J. Int. Bus. Stud. 2006, 37 (6): 863-878. doi:10.1057/palgrave.jibs.8400231

6. Conger, J.A. Motivate Performance through Empowerment. In: Locke, E.A. (Eds.), The Blackwell handbook of principles of organisational behaviour. Blackwell Publishing Ltd., Oxford (UK) (2003): 143-156.

7. Costa, J. Carrots or Sticks: Which Policies Matter the Most in Sustainable Resource Management? Resources 2021, 10 (2): 12. doi:10.3390/resources 10020012

8. Costa, J.; Matias, J.C.O. Open Innovation 4.0 as an Enhancer of Sustainable Innovation Ecosystems. Sustainability (Basel) 2020, 12 (19): 8112. doi:10.3390/su12198112

9. Eidelwein, F.; Cisco Collatto, D.; Rodrigues, L.H.; Pacheco Lacerda, D.; Sartori Piran, F. Internalization of environmental externalities: Development of a method for elaborating the statement of economic and environmental results. J. Clean. Prod. 2018, 170: 1316-1327. doi:10.1016/j.jclepro.2017.09.208

10. Eisenmenger, N.; Pichler, M.; Krenmayr, N.; Noll, D.; Plank, B.; Schalmann, E.; Wandl, M.-T.; Gingrich, S. The Sustainable Development Goals prioritise economic growth over sustainable resource use: a critical reflection on the SDGs from a socio-ecological perspective. Sustain. Sci. 2020, 15: 1101-1110. doi:10.1007/s11625020-00813-X

11. Emara, N.; Chiu, I.-M. The impact of governance on economic growth: the case of Middle Eastern and North African countries. Topics in Middle Eastern and African Economies 2016, 18 (1): 126-144.

12. Everett, T.; Ishwaran, M.; Ansaloni, G.P.; Rubin, A. Economic growth and the environment. Defra Evidence and Analysis Series, Paper 2 (2010). $51 \mathrm{p}$.

13. Folkens, L.; Wiedemer, V.; Schneider, P. Monetary Valuation and Internalization of Externalities in German Agriculture Using the Example of Nitrate Pollution: A Case-Study. Sustainability (Basel) 2020, 12 (16): 6681. doi:10.3390/su12166681

14. García-Gusano, D.; Istrate, R.; Iribarren, D. Life-cycle consequences of internalising socio-environmental externalities of power generation. Sci. Total Environ. 2018, 612: 386-391. doi:10.1016/j.scitotenv.2017.08.231 
15. Gelb, S.; Islam, B.; Mason, N.; Gatune, J.; Kweka, J. Business impact on reform of private economic governance. Business Environment Reform Facility (BERF) (2019). Available Online: https://assets.publishing.service.gov.uk/media/5ca628fbed915d0c57e 97ec8/BERF_Business_Impact_on_Private_Economic_Governance_ 28_March_2019.pdf

16. Goosen, M.F.A. Environmental management and sustainable development. Procedia Engineering 2012, 33: 6-13. doi:10.1016/j.proeng.2012.01.1171

17. Guest, D.E. Human resource management and performance: a review and research agenda. Int. J. Hum. Resour. Manag. 1997, 8 (3): 263276. doi:10.1080/095851997341630

18. Hadj Fraj, S.; Hamdaoui, M.; Maktouf, S. Governance and economic growth: The role of the exchange rate regime. International Economics 2018, 156: 326-364. doi:10.1016/j.inteco.2018.05.003

19. IPCC. Adaptation to climate change in the context of sustainable development and equity. In: McCarthy J.J. et al. (Eds), Climate Change 2001: Impacts, Adaptation, and Vulnerability. Contribution of Working Group II to the Third Assessment Report of the Intergovernmental Panel on Climate Change (2001): 877-912.

20. Janssen, M.; van der Voort, $\mathrm{H}$. Agile and adaptive governance in crisis response: lessons from the COVID-19 pandemic. Int. J. Inform. Manage, 2020, 55: 102180. doi:10.1016/j.ijinfomgt.2020.102180

21. Krechovská, M.; Procházková, P.T. Sustainability and its integration into corporate governance, focusing on corporate performance management and reporting. Procedia Engineering 2014, 69: 11441151. doi:10.1016/j.proeng.2014.03.103

22. Liu, J.; Tang, J.; Zhou, B.; Liang, Z. The effect of governance quality on economic growth: based on China's provincial panel data. Economies 2018, 6 (4): 56. doi:10.3390/economies6040056

23. Macellari, M.; Yuriev, A.; Testa, F; Boiral, O. Exploring bluewashing practices of alleged sustainability leaders through a counteraccounting analysis. Environ. Impact Assess. Rev. 2021, 86: 106489. DOI: 10.1016/j.eiar.2020.106489

24. Nair, S.R. The link between women entrepreneurship, innovation and stakeholder engagement: A review. Journal of Business Research 2019, 119: 283-290. doi:10.1016/j.jbusres.2019.06.038

25. OECD. Building a coherent response for a sustainable post-COVID19 recovery. ECD Policy Responses to Coronavirus (COVID-19). Organisation for Economic Co-operation and Development (OECD). Available Online: https://www.oecd.org/coronavirus/policy- 
responses/building-a-coherent-response-for-a-sustainable-post-covid19-recovery-d67eab68/

26. Ong, T.; Trireksani, T.; Djajadikerta, H.G. Hard and soft sustainability disclosures: Australia's resources industry. Account. Res. J. 2016, 29 (2): 198-217. doi:10.1108/ARJ-03-2015-0030

27. Ong, T.; Djajadikerta, H.G. Corporate governance and sustainability reporting in the Australian resources industry: an empirical analysis. Social Respons. J. 2018, 16 (1): 1-14. doi:10.1108/SRJ-062018-0135

28. Schaltegger, S.; Hörisch, J. In search of the dominant rationale in sustainability management: legitimacy-or profit-seeking? J. Bus. Ethics 2017, 145 (2): 259-276. doi:10.1007/s10551-015-2854-3

29. Schneider, H. Participatory governance: The missing link for poverty reduction. Policy Brief No. 17, OECD Development Centre (1999): 30 p.

30. Schulte, J.; Hallstedt, S.I. Company risk management in light of the sustainability transition. Sustainability (Basel) 2018, 10 (11): 4137; doi:10.3390/su10114137

31. Stankevičiūtè, Z.; Savanevičienè, A. Designing sustainable HRM: The core characteristics of emerging field. Sustainability (Basel) 2018, 10 (12): 4798. doi:10.3390/su10124798

32. Stofkova, Z; Sukalova, V. Sustainable development of human resources in globalisation period. Sustainability (Basel) 2020, 12 (18): 7681. doi:10.3390/su12187681

33. Thistlethwaite, J.; Menzies, M. Assessing the governance practices of sustainability reporting. Centre for International Governance Innovation (CIGI), Policy Brief No. 71, (2016). Available Online: www.jstor.org/stable/resrep16159

34. UN General Assembly. Report of the world commission on environment and development: Our common future. Oslo, Norway: United Nations General Assembly, Development and International Cooperation: Environment, (1987).

35. United Nations Global Compact; Accenture Strategy. The UN Global Compact-Accenture Strategy CEO Study 2016, Agenda 2030: A Window of Opportunity. Accenture Strategy, New York, (2016).

36. UN-SDG. The 17 Goals - Sustainable Development Goals. Department of Economic and Social Affairs, the United Nations (UN). Available Online: https://sdgs.un.org/goals

37. Uysal, G. Impact of Human Resource Management on Economy: Firm Management Perspective. Manag. Stud. 2017, 5 (4): 308-311. doi:10.17265/2328-2185/2017.04.005 
38. Vlad, C.A.; Ungureanu, G.; Militaru, M. Human Resources Contribution To Economic Growth. Revista Economica 2012, 1/2012: 850-860.

39. Warford, J.; Schramm, G. (1987). Environmental management and economic development. Ann. Regional Sci. 1987, 21 (3): 12. doi:10.1007/bf01287278

40. Willumsen, P.; Oehmen, J.; Stingl, V.; Geraldi, J. Value creation through project risk management. Int. J. Project Manag. 2019, 39: 731-749. doi:10.1016/j.ijproman.2019.01.007 